\title{
Liberalism, Marxism and Democratic Theory Revisited: Proposal of a Joint Index of Political and Economic Democracy
}

\author{
Angelo Segrillo \\ Department of History, University of São Paulo
}

\begin{abstract}
Liberalism and Marxism are two schools of thought which have left deep imprints in sociological, political and economic theory. They are usually perceived as opposite, rival approaches. In the field of democracy there is a seemingly insurmountable rift around the question of political versus economic democracy. Liberals emphasize the former, Marxists the latter. Liberals say that economic democracy is too abstract and fuzzy a concept, therefore one should concentrate on the workings of an objective political democracy. Marxists insist that political democracy without economic democracy is insufficient.

The article argues that both propositions are valid and not mutually exclusive. It proposes the creation of an operational, quantifiable index of economic democracy that can be used alongside the already existing indexes of political democracy. By using these two indexes jointly, political and economic democracy can be objectively evaluated. Thus, the requirements of both camps are met and maybe a more dialogical approach to democracy can be reached in the debate between liberals and Marxists. The joint index is used to evaluate the levels of economic and political democracy in the transition countries of Eastern Europe.
\end{abstract}

Keywords: democratic theory; transition countries; economic democracy

\section{Introduction}

T iberalism and Marxism are two schools of thought which have left deep imprints

Uin political, sociological and economic theory. Both have been very fruitful in illuminating a wide range of common issues across these fields and yet are usually perceived 
as opposite, rival approaches contradicting each other in general. The fall of the Soviet Union and the socialist countries in Eastern Europe obliged Marxist and liberal theorists to make further efforts to understand this process - the former to comprehend the crumbling of communism, the latter interested in the political and economic transition to capitalism. Due to the circumstances surrounding these developments - seemingly the complete victory of one side over the other - the common task to analyze the perestroika and transition experience did not lead to a coming closer of the two contending views, but may have even led to a deepening of the gulf between them.

This article argues that liberalism and Marxism are extremely useful approaches and are not mutually exclusive. I propose some first steps towards a synthesis between them exactly in relation to one of their greatest bones of contention - the issue of democracy. No grand synthesis will be offered here, but rather the humble beginning of an effort to bring the more moderate contenders from each side to utilize some of their specific insights to co-jointly better illuminate this complex matter. In practice, I will propose the creation of a new, alternative index for measuring democracy, which incorporates liberal and Marxist insights and can therefore be more acceptable to both sides than the presently existing ones. It is my hope that if we can create an index that is acceptable to both sides, this may lead to joint collaborative research which will deepen our present understanding of democracy and of the difficulties it still faces in being fully accepted in many parts of the world.

The article is composed of three sections - a presentation of how the problem of democracy historically arose between liberalism and Marxism; the proposal of a preliminary synthesis of the Marxist and liberal views via the creation of a joint index of democracy which incorporates insights from both camps; and an initial application of this index to the transition countries of Eastern Europe.

Since we will focus on the experience of transition countries, we will start by describing the definitions of democracy used in the studies of transition.

\section{Concept of Democracy in Transition Studies}

The concept of democracy arose a long time ago and has been a highly controversial one, but the version used by most mainstream political scientists (especially transitologists) has its roots in Joseph Schumpeter's $(1984,336)$ famous minimalist definition of democracy as "that institutional arrangement for arriving at political decisions in which individuals acquire the power to decide by means of a competitive struggle for the people's vote." In other words, democracy is characterized by the existence of competitive elections for the executive and legislative posts instead of them being filled by means of hereditary 
succession, violent revolutionary means, etc. According to Schumpeter, this is a descriptive definition, i.e., one that describes in an objective manner what modern democracies are like, thus avoiding subjective, normative definitions which prescribe what an ideal democracy should be like according to each author's worldview. As Samuel Huntington puts it:

In his path-breaking study, Capitalism, Socialism and Democracy, Schumpeter spelled out the deficiencies of what he termed the "classical theory of democracy", which defined democracy in terms of "the will of the people" (source) and "the common good" (purpose) [...]

For some while after World War II a debate went on between those determined, in the classical vein, to define democracy by source or purpose and the growing number of theorists adhering to a procedural concept of democracy in the Schumpeterian mode. By the 1970's the debate was over and Schumpeter had won. Theorists increasingly drew distinctions between rationalistic, utopian, idealistic definitions of democracy, on one hand, and empirical, descriptive, institutional and procedural definitions, on the other, and concluded that only the latter types of definition provided the analytical precision and empirical referents that make the concept a useful one. Sweeping discussions of democracy in terms of normative theory sharply declined, at least in American scholarly discussions, and were replaced by efforts to understand the nature of democratic institutions, how they function, and the reasons why they develop and collapse (Huntington 1991, 6-7).

Thus, Schumpeter's minimalist concept of democracy lies at the base of current mainstream Western political science. It is especially influential in the field of study of democratic transitions (Huntington 1991, 7; O'Donnell and Schmitter 1988, 26; Przeworski 1991, 10; Przeworski et al. 1997, 114; Schmitter \& Karl 1996, 50). Definitions of democracy used in the study of countries in democratic transition are "Schumpeter's heirs" in the sense that they owe greatly to that Austrian thinker. Especially if we take into consideration O'Donnel's warning about the "not-so-minimalist" character of Schumpeter's definition, ${ }^{1}$ we must acknowledge that most definitions presently used reveal themselves as more or less sophisticated variations of the Schumpeterian original matrix. For example,

democracy is...

[...] a regime in which government posts are filled by means of competitive elections. A regime is democratic only if the opposition [can] compete for, win and take charge of these posts (Przeworski et al. 1997, 131).

[A political system in which] the most powerful decision makers are elected through fair, honest and periodic elections in which candidates freely compete for votes and in which virtually all the adult population is eligible to vote (Huntington 1991, 7). 
[...] a system of governance in which rulers are held accountable for their actions in the public realm by citizens, acting indirectly through the competition and cooperation of their elected representatives (Schmitter \& Karl 1996, 50).

[...] a system of government that meets three essential conditions: meaningful and extensive competition among individuals and organized groups (especially political parties) for all effective positions of government power, at regular intervals and excluding the use of force; a highly inclusive level of political participation in the selection of leaders and policies, at least through regular and fair elections, such that no major (adult) social group is excluded; and a level of civil and political liberties - freedom of expression, freedom of the press, freedom to form and join organizations - sufficient to ensure the integrity of political competition and participation (Diamond et al. 1989, xvi).

These are some of the most important theorists of democratic transition and consolidation processes in the world today. Their definitions, from the first two more minimalist to the last more elaborated one, like Schumpeter's, place democracy's greatest emphasis on the method of choosing the rulers (and the possibility of becoming a ruler oneself), emphasizing that elections must be "clean" and "competitive", which pre-supposes a series of civil and political liberties.

Schumpeter's concept of democracy has been criticized from different points of view (e.g., Held 1987, 178-85), but I herein want to draw attention to one specific facet of the problem. Procedural (descriptive) definitions of democracy of the Schumpeterian type turn liberal, representative democracy into the only possible type of real democracy. In it, the main political role of the great mass of the population is to elect (and kick out), with great freedom and in a competitive way, those special citizens who will represent them in the executive and legislative branches of government. According to Schumpeter's intellectual heirs, historical experience has shown that it was with this model of political organization that modern societies have reached the greatest degree of freedom for their citizens. However, the elevation of liberal, representative democracy to the status of sole valid paradigm brings with it contradictions with definitions of democracy, based on its historical and etymological origins. Let us examine this in greater detail.

\section{The Origins of Democracy}

Etymologically speaking, the word democracy comes from the Greek demokratia (demos, "people", kratia linked to Kratos, "force", "power" and kratein, "rule", "govern") meaning "power of the people", "rule of the people". It referred to the government system of Athens in the $5^{\text {th }}$ century BC. In Athens every (male adult) citizen could himself vote in the Assembly (eklesia) on the most important questions of the city. Apart from the eklesia 
— which met at least ten times a year - Athenian citizens elected a council (boule) made up of 500 people who exercised executive power, running daily business, putting into practice the decisions of the Assembly, preparing the agenda of its future meetings, etc. The members were elected for a one-year period. This Council was divided into committees of 50 members, each committee governing for a period of one tenth of the year. Since nobody was allowed to remain on the Council of 500 for more than two years, ordinary citizens had a good opportunity to serve on it at some point in their lives. Rotation in government posts was considered a good method to escape the formation of oligarchies and ensure participation. Athenian "politicians" in general were then not professionals but amateurs. ${ }^{2}$

Thus, in its Greek origins, democracy was direct, i.e., the citizens voted personally and directly in the Assembly and the executive power of the Council of 500 was not exercised by a separate class of politicians but rather by the citizens themselves in alternation. Democracy was a new form of government in which the citizenry as a whole could exert power, in opposition to the previous regimes of monarchy/tyranny (one-man rule) or aristocracy/oligarchy (rule of the few). The will of the majority of citizens ought to be the basis for the final decisions.

The main point, as far as our discussion is concerned, is that democracy, in its origins, was basically direct (no "middleman"). It is important to emphasize this fact because, after its heyday in Athens, democracy went through a centuries-long eclipse. Except for a few isolated cases, democracy reappeared as a political regime only after the "democratizing shock" by the French Revolution (1789) and the American War of Independence (17751781) on the principles of political liberalism originated in the English Glorious Revolution (1689). Liberalism in its 17th-century beginnings was an elitist doctrine. It was only after the democratizing shock of the French and American Revolutions that liberalism started vigorously expanding the suffrage to wider parts of the population, thus starting to form what we now call liberal democracy. The goal of a liberal democracy was to allow participation of greater portions of the population as electors and potential candidates (for government posts), at the same time trying to keep the public and private spheres separate, restraining government so that it would not become tyrannical over the individual. Thus, liberal democracy became an indirect democracy. Due to the excessively large size of the new nation-states, it was not any more possible for the people to directly exert power in Greek eklesia-like assemblies and therefore it became necessary that citizens elect representatives to a smaller Parliament, which would then take the proper final decisions.

\section{Direct and Indirect Democracy - Controversies}

When we say that current "Schumpeterian" concepts of democracy emphasize the competitive election of rulers we notice that this view "freezes", and turns into a paradigm 
the representative (indirect) type of democracy. Moreover it elevates to a pedestal exactly what Rousseau (and also, from another angle, the defenders of direct democracy) considered the one thing capable of emptying out the very essence of democracy: the election of autonomous "representatives" of the citizens who legislate au lieu of them. For Rousseau, people's sovereignty is non-transferable; either people exert it directly or it does not exist. Therefore his ironical comment on the "liberal" political system of Britain in the 18th century:

Sovereignty cannot be represented for the same reason that it cannot be alienated [...] The deputies of the people, therefore, are not and cannot be their representatives; they can only be their commissioners, and as such are not qualified to conclude anything definitely. No act of theirs can be a law, unless it has been ratified by the people in person; and without that ratification nothing is a law. The people of England deceive themselves when they fancy they are free; they are so, in fact, only during the election of members of parliament; for, as soon as a new one is elected, they are again in chains, and are nothing (Rousseau 1947, 85).

In modern jargon, Rousseau at best accepted what we call the imperative mandate for deputies, by which these merely fulfill pre-arranged orders from the voters. But he would never accept the autonomy of those elected deputies, for it would be a form of alienating sovereignty, and sovereignty, according to him, is inalienable. ${ }^{3}$

Thus, we notice that definitions of a Schumpeterian kind, which make legislative representation (under liberal conditions) synonymous with democracy, find themselves in conflict with some currents of "classical" democracy, which view sovereignty as emanating directly from the people and inseparable from it in the act of law-making. We also saw that the conception of democracy of the ancient Greeks emphasized the citizens voting their laws directly in the Assembly (eklesia) while the executive power was vested in a rotating collective body of citizens, the Council of 500 (boule). According to this model, democracy should literally mean "the government of the people", ${ }^{4}$ as indicated in the etymological roots of the word. It is necessary to draw attention to the fact that Schumpeterian-type definitions of democracy do not easily fit together with either the etymological or historical roots of the concept. On the contrary, they go against the essence of the original model of democracy when they (according to Rousseau) take away sovereignty (i.e., the power to rule or legislate over oneself) from the people and transfer it to a chosen few.

These observations can be viewed as petty nostalgia for some forgotten, golden past in which, due to the limited size of the city-states, direct democracy was possible. However, the question is more complicated. The central problem is as follows. If democracy is really to be a "government of the people" and we accept the impossibility of having direct democracy in present-day large nation-states, ${ }^{5}$ then the only way to have a true representative democracy would be to make certain that Parliament and government (i.e., the 
elected body) reflected exactly (or very closely) the proportions of preferences of the body of electors. If this condition is not realized, then we do not have a democracy but, at best, a mixed type of government with elements of aristocracy. Moreover, even if Parliament reflects "the people", in real life a problem frequently arises which we may call parliamentary "refraction", i.e., the disassociation of the interests of electors and the elected once the electoral campaign is over and real legislative activity begins.

Those who attentively observe the political scene in different countries notice that the above-mentioned refractive phenomenon indeed occurs and often the elected do not reflect the wishes (or even the ultimate interests) of the electors once they are well established in the "House of the People". This is not a problem according to Schumpeter's definition because he does not stipulate an imperative mandate for the deputies, but rather the utmost freedom for the elected politicians to pursue their causes according to their personal conscience. Like James Madison (1999, 160-167) in Federalist Paper No. 10, Schumpeter thinks that an elite of capable parliamentarians chosen from among the best options by the people will be in better condition to discuss and decide about the complex political issues than the general mass of people as a whole, the majority of whom do not have the technical skills or knowledge to best tackle these questions.

If in Schumpeterian democracy the political role of the people is basically to elect (and kick out) a governing elite, we come to the following dilemma. Doesn't changing the focus of democracy from searching for the best way for the people to self-govern and placing it on the institutionalization of a method of inclusive formation of autonomous political elites mean to abandon the very essence of democratization?

Schumpeter's attempt at creating a "descriptive" definition of modern democracy comes up against epistemological difficulties. Would it not be a tautology to define democracy by the mere description of the regimes considered democratic? How could Schumpeter know that these regimes were really democratic if he did not have an a priori definition of democracy?

These represent a group of problems regarding the Schumpeterian view of democracy on an abstract, theoretical plane. However, even if we disregard these issues stemming from the point of view of direct democracy, there is still another problem with the conception of democracy of the present "heirs of Schumpeter", namely the unresolved question of the interaction between political and economic democracy. And that is the great bone of contention with Marxists.

\section{The Socialist Objections}

Even not taking into account some considerations which would be essential to the more literal defenders of direct democracy (such as the difficulty in achieving a faithful 
proportional representation of the electorate in Parliament, the problem of the divergence of opinions and positions of the electors and the elected in the post-election period, the Rousseauian problem of alienation of sovereignty, etc.), there is still a basic objection put forth by socialists in the 19th century which has not yet been adequately answered: the objection that political democracy without economic democracy is insufficient to qualify a society as fully democratic.

The most forceful formulation of this objection was Lenin's famous diatribe in The State and Revolution:

In capitalist society, under the conditions most favourable to its development, we have a more or less complete democracy in the democratic republic. But this democracy is always bound in by the narrow framework of capitalist exploitation, and consequently always remains, in reality, a democracy for the minority, only for the possessing classes, only for the rich. Freedom in capitalist society always remains just about the same as it was in the ancient Greek republics: freedom for the slave-owners [...]

Marx splendidly grasped this essence of capitalist democracy when, in analyzing the experience of the [Paris] Commune, he said that the oppressed were allowed, once every few years, to decide which particular representatives of the oppressing class should be in parliament to represent and repress them! (Lenin 1943, 71-73)

In the passage above, Lenin puts forth a series of questions that reflect the socialist criticism of the insufficiencies of political democracy unaccompanied by economic democracy. How can one believe that the "vote" ( = the power to elect) of a slum dweller has the same weight as that of, say, Ted Turner, who owns influential media? "One person, one vote" is the basic principle of all definitions of democracy above. But if the real voting power (i.e., the real capacity to "make" rulers) of citizens vary according to their wealth, their access to or domination of the means of communication, then can it be considered a real democracy?

The question of the control of the means of communication is especially crucial because the capacity of the citizen-owners of the big media to influence the rest of the citizenry makes their "vote" (their real capacity to influence policies) much greater than average.

However, the socialist criticism of bourgeois democracy goes deeper than that. It says that capitalist society is inherently undemocratic because if the means of production are concentrated in the hands of a minority class, and not socialized throughout the population, these unequal conditions will influence the strictly political field as well. Socialists ask why bourgeois democrats demand equality in the political field only. What is the reason for not expanding equality into the economic field as well? Liberal political scientists 
restrict democratic equality to the political sphere, refusing to expand it to the economic field. As two famous transitologists put it in an influential work:

The advent of political democracy is the preferred terminus ad quem of our interpretative effort, but it is not the end of struggles over the form and purpose of politics [...] In a sense, the transition to political democracy sets up the possibility — but by no means, the inevitability — of another transition.

[...] We have called this "second" transition "socialization" [...] In this context, all we can do is reaffirm our earlier presumption that political democracy per $s e$ is a goal worthy of attainment, even at the expense of forgoing alternative paths that would seem to promise more immediate returns in terms of socialization (O’Donnell and Schmitter 1988, 30-33).

This passage is emblematic because it highlights the dilemma of the gulf between the two positions. For liberals, political democracy is an end in itself, independently of economic democratization. On the other hand, the socialist/Marxist critics state that without economic democracy bourgeois political democracy is insufficient. ${ }^{6}$

\section{The Marxist/Liberal Divide}

Where do we stand on this issue? At present we find this deadlock: liberals refuse to leave the safe haven of political democracy and extend their reach to economic democracy; revolutionary Marxists dwell on economic democracy and refuse to go without it to political democracy.

In order to cross the sea that separates these two continents, I propose the following research agenda: is it possible to come up with a "unified field" theory of democracy? In other words, is it possible to create a method that simultaneously evaluates (measures) the advances (and setbacks) in the fields of political democracy and economic democracy?

The possibility (or functionality) of such unified theory is denied by both the liberal and the Marxist sides. The post-Schumpeterian liberals say that the inclusion of economic democracy would be a complicating, highly subjective extra factor, which would undermine the concision, precision, functionality and objectivity typical of today's minimalist, procedural definitions of democracy (Huntington 1991, 9; Mainwaring et al. 2001, 651). On the other hand, radical Marxists, in the footsteps of Lenin (1943, 71-73), affirm that liberal democracy "is always bound by the narrow framework of capitalist exploitation, and consequently always remains, in reality, a democracy for the minority, only for the possessing classes" and that a real government of the people may only develop in a society in which the means of production are socialized - therefore, it is a useless pastime to measure [the illusion of] political democracy in capitalist countries. As we see, one 
side refuses to measure the level of economic democracy and the other side of political democracy.

We must admit that the search for this "unified field" democratic theory is very difficult. The spheres of political democracy and economic democracy seem so qualitatively different that the possibility of a joint measurement may turn out to be a Herculean, even Sisyphean task. However, this is a necessary effort for the sake of objective research on democratization. Take the case of two democratizing regions, for instance, Latin America and Eastern Europe. Some transitologists have written sophisticated work comparing the democratization efforts in these two regions (Przeworski 1991; Nelson 1994; Greskovits 1998). If in the analysis of the "South", a minimalist, Schumpeterian approach to democracy (centered on the political side) is facilitated by the fact that the economic basis in the region (capitalism) is the same before and after the transition (thus justifying the concentration on the political aspect), the same does not hold true for the "East". In the former socialist countries of Eastern Europe, the economic base changed completely from the beginning of transition (socialism) to the end (capitalism). In this case, it is difficult not to take into account the consequences of the transformation on the economic side (i.e., also measure the changes in economic democracy). Due to the structural differences in the original modes of production these regions started off from, the comparative evaluation of the gains and losses the populations in the "South" and the "East" had with these transformations (and also the comparisons between capitalism and socialism in general) are in need of a synthetic breakthrough in the field of evaluation of political and economic democracy. Such a breakthrough might allow a common language for Marxist and non-Marxist political scientists in their analyses of the transformations of the former socialist countries in general.

A first, prosaic step in this direction could be the establishment of an extra item in rankings like those of Freedom House (the organization that evaluates quantitatively the level of political democracy in the countries of the world). Besides measuring political democracy, I would propose that we also measure economic democracy (i.e., the degree of equal access of citizens to the means of production and wealth of the nation) by using the provisional proxy of the Gini coefficient. ${ }^{7}$ In order to avoid the trappings of using a more sophisticated, subjective measurement of economic democracy, which might reduce its concision, simplicity and functionality, the use of the Gini coefficient, which measures the degree of income inequality, may be a good provisional operational proxy and may allow Marxists and liberals to start using the common language of numbers as a modest beginning towards greater future understanding around this hypothetically enlarged ranking of democracy of the new Freedom House of the future. ${ }^{8}$ 


\section{The New Joint Index of Political and Economic Democracy}

As we saw, the main difficulty in bringing together liberals and Marxists in creating a common measurement of democracy is that liberals say that economic democracy, unlike political democracy in its minimalist definition, is too abstract a concept to be quantified and operationalized, whereas Marxists refuse to take into account political democracy without economic democracy. Therefore, if we could find a quantifiable and functional index for economic democracy, this could be a great step forward. Since economic democracy is really an abstract and controversial concept - for example, a completely stateowned economy would signify that everybody has control of the means of production or that nobody has control of them? - we proposed a proxy, which is the Gini coefficient of income differentials. As mentioned earlier, the fact that the Gini coefficient does not relate directly to the ownership of the means of production, it may even turn out to be an asset. It creates a "healthy" competition for which system or regime, in practice, shows better distributive justice, regardless of the form of ownership of the means of production. Of course, the Gini coefficient is far from a perfect index, even in its own terms, but it may be regarded as a valid, provisional (until a better indicator is found) first step towards an attempt to jointly measure political and economic democracy.

For the purpose of presenting an illustration of how this index can be built we propose the following exercise. For economic democracy we will use the Gini coefficient of different countries as presented in the World Income Inequality Database of the United Nations University (2005) and in the TransMONEE (2006) database of the Innocenti Research Center of UNICEF.

Our index for political democracy will be the arithmetic mean between the scores of political rights and civil liberties assigned by Freedom House to each country every year. ${ }^{9}$ In order to make our indicators for Economic Democracy and Political Democracy comparable, we will present both of them in a scale from zero to ten, with zero being the worst score (i.e., least equal or least democratic) and ten the best score (the most equal or the most democratic). Finally, our joint index of political and economic democracy will be the arithmetic mean between these two indicators on the scale from zero to ten. The result is shown in Table 1. 
Table 1. Ratings of Economic Democracy, Political Democracy and Combined Score

\begin{tabular}{|c|c|c|c|c|c|c|c|c|c|c|c|c|}
\hline & \multicolumn{3}{|c|}{1989} & \multicolumn{3}{|c|}{$\begin{array}{l}2004 \\
\text { (or most recent avail- } \\
\text { able Gini C. data) }\end{array}$} & \multicolumn{3}{|c|}{2006} & \multicolumn{3}{|c|}{$(1989-2006)$} \\
\hline & ED & PD & $\begin{array}{l}\text { Mean } \\
\text { ED/ } \\
\text { PD }\end{array}$ & $\mathrm{ED}$ & $\mathrm{PD}$ & $\begin{array}{l}\text { Mean } \\
\text { ED/PD }\end{array}$ & ED & $\mathrm{PD}$ & $\begin{array}{l}\text { Mean } \\
\text { ED/ } \\
\text { PD }\end{array}$ & $\begin{array}{l}\text { Variation } \\
\text { ED }\end{array}$ & $\begin{array}{l}\text { Variation } \\
\text { PD }\end{array}$ & $\begin{array}{l}\text { Variation } \\
\text { ED/PD }\end{array}$ \\
\hline Armenia & 7.5 & 2.5 & 5.0 & 5.4 & 4.2 & 4.8 & & 4.2 & & -2.1 & +1.7 & -0.2 \\
\hline Azerbaijan & 6.9 & 2.5 & 4.7 & 4.9 & 2.5 & 3.7 & & 2.5 & & -2.0 & 0 & -1.0 \\
\hline Belarus & 7.7 & 2.5 & 5.1 & 7.5 & 0.8 & 4.2 & & 0.8 & & -0.2 & -1.7 & -0.9 \\
\hline Bulgaria & 7.7 & 0 & 3.9 & 6.4 & 9.2 & 7.8 & & 9.2 & & -1.3 & +9.2 & +3.9 \\
\hline $\begin{array}{l}\text { Czech } \\
\text { Republic }\end{array}$ & 8.0 & 1.7 & 4.9 & 7.6 & 10 & 8.8 & & 10 & & -0.4 & +8.3 & +3.9 \\
\hline Estonia & 7.2 & 2.5 & 4.9 & 6.0 & 9.2 & 7.6 & & 10 & & -1.2 & +7.5 & +2.7 \\
\hline Georgia & 7.2 & 2.5 & 4.9 & 5.5 & 5.0 & 5.3 & & 6.7 & & -1.7 & +4.2 & +0.4 \\
\hline Hungary & 7.8 & 5.8 & 6.8 & 7.3 & 9.2 & 8.3 & & 10 & & -0.5 & +4.2 & +1.5 \\
\hline Kazakhstan & 7.2 & 2.5 & 4.9 & & & & & 2.5 & & & 0 & \\
\hline $\begin{array}{l}\text { Kyrgyz } \\
\text { Republic }\end{array}$ & 7.3 & 2.5 & 4.9 & 6.2 & 2.5 & 4.4 & & 4.2 & & -1.1 & +1.7 & -0.5 \\
\hline Lithuania & 7.4 & 2.5 & 5.0 & 6.9 & 8.3 & 7.6 & & 10 & & -0.5 & +7.5 & +2.6 \\
\hline Latvia & 7.4 & 2.5 & 5.0 & 6.2 & 9.2 & 7.7 & & 10 & & -1.2 & +7.5 & +2.7 \\
\hline Moldova & 7.5 & 2.5 & 5.0 & 5.8 & 5.8 & 5.8 & & 5.8 & & -1.7 & +3.3 & +0.8 \\
\hline Poland & 7.2 & 5.8 & 6.5 & 6.3 & 10 & 8.2 & & 10 & & -0.9 & +4.2 & +1.7 \\
\hline Romania & 7.6 & 0 & 3.8 & 6.4 & 7.5 & 7.0 & & 8.3 & & -1.2 & +8.3 & +3.2 \\
\hline $\begin{array}{l}\text { Russian } \\
\text { Federation }\end{array}$ & 7.3 & 2.5 & 4.9 & 5.1 & 3.4 & 4.3 & & 2.5 & & -2.2 & 0 & -0.6 \\
\hline $\begin{array}{l}\text { Slovak } \\
\text { Republic }\end{array}$ & 8.0 & 1.7 & 4.9 & 7.0 & 9.2 & 8.1 & & 10 & & -1.0 & +8.3 & +3.2 \\
\hline Tajikistan & 7.2 & 2.5 & 4.9 & & & & & 2.5 & & & 0 & \\
\hline Turkmenistan & 7.2 & 2.5 & 4.9 & & & & & 0 & & & -2.5 & \\
\hline USSR & 7.3 & 2.5 & 4.9 & & & & & & & & & \\
\hline Ukraine & 7.7 & 2.5 & 5.1 & 6.7 & 5.0 & 5.9 & & 7.5 & & -1.0 & +5.0 & +0.8 \\
\hline Uzbekistan & 7.2 & 2.5 & 4.9 & & & & & 0 & & & -2.5 & \\
\hline
\end{tabular}

Note:

$\mathrm{ED}=$ Economic Democracy $; \mathrm{PD}=$ Political Democracy $; \mathrm{ED} / \mathrm{PD}=$ combined score of ED and PD (arithmetic mean between ED and PD).

The score for Economic Democracy is the Gini coefficient of income inequality of each country expressed in an inverted scale from zero (total inequality) to ten (total equality). The score for Political Democracy is the arithmetic mean of the Freedom House ratings for political rights and civil liberties of each country expressed in a scale from zero (least democratic) to ten (most democratic). The Gini coefficients for all countries, except for the USSR and the Russian Federation, are from TransMONEE 2006. The data for the USSR, the Russian Federation, the 1989 data for the Czech and Slovak republics, and the 2002 data for Azerbaijan are from former TransMONEE database versions as presented in the UNU-WIDER database.

The 1989 PD score for the Soviet Union was used as a proxy for PD scores of the Soviet Republics in 1989. The 1989 PD score for Czechoslovakia was used as a proxy for PD scores of the Czech and Slovak republics in 1989.

The columns under "2004 or most recent available Gini Coefficient data" show ED, PD and Mean ED/PD for the most recent year for which the Gini Coefficient data is available for each country: 2004 for Armenia, Belarus, Bulgaria, the Czech Republic, the Kyrgyz Republic, Latvia, Lithuania, Moldova, Poland, and Romania; 2003 for Estonia, Hungary and the Slovak Republic; 2002 for Azerbaijan, Georgia, the Russian Federation, and Ukraine.

The columns "Variation" show the rise or decline in points from the end period of the socialist regime (year 1989) to the most recent year available for each indicator separately.

Occasional discrepancies in decimals are due to rounding of numbers in the process of calculation.

Source: TransMONEE 2006 database at http://www.unicef.icdc.org/resources/transmonee.html; UNU-WIDER World Income Inequality Database at http://www.wider.unu.edu/wiid/wiid.htm; Freedom House homepage at http://www.freedomhouse.org. 


\section{What the new index tells us}

The table with the new index was designed to measure the difference the populations of the transition countries experienced between the end period of the former socialist regime and recent years in terms of economic democracy, political democracy and both simultaneously. Let us analyze them separately.

All countries in this survey had a drop in their level of economic democracy. Their income inequality (as measured by the Gini coefficient) worsened — in some nations more than others. The greatest decrease in income equality was in the Russian Federation (from 7.3 to $5.1=-2.2$ ), Armenia (from 7.5 to $5.4=-2.1$ ), Azerbaijan (from 6.9 to $4.9=-2.0$ ), Georgia (from 7.2 to $5.5=-1.7$ ) and Moldova (from 7.5 to $5.8=-1.7$ ). The ones that had the smallest falls in the item Economic Democracy were Belarus (from 7.7 to $7.5=-0.2$ ), the Czech Republic (from 8.0 to $7.6=-0.4$ ), Hungary (from 7.8 to $7.3=-0.5$ ) and Lithuania (from 7.4 to $6.9=-0.5$ ).

In terms of political democracy, the worst performers in this period were: Turkmenistan and Uzbekistan (both from 2.5 to zero $=-2.5$ ); Belarus (from 2.5 to $0.8=-1.7$ ); and Tajikistan, Kazakhstan, Azerbaijan and the Russian Federation (all four having in 2006 the same level of PD [i.e., 2.5] as in 1989). The largest advancement in political democracy as compared to 1989 went to Bulgaria (from 0 to $9.2=+9.2$ ), the Czech Republic (from 1.7 to $10=+8.3$ ), the Slovak Republic (from 1.7 to $10=+8.3$ ) and Romania (from 0 to $8.3=+8.3)$.

If we take the combined index of political and economic democracy, the greatest improvements also go to Bulgaria (from 3.9 to $7.8=+3.9$ ), the Czech Republic (from 4.9 to $8.8=+3.9$ ), the Slovak Republic (from 4.9 to $8.1=+3.2$ ), and Romania (from 3.8 to 7.0 $=+3.2$ ). The greatest falls in the joint index were those of Azerbaijan (from 4.7 to $3.7=$ -1.0 ), Belarus (from 5.1 to $4.2=-0.9$ ), the Russian Federation (from 4.9 to $4.3=-0.6$ ) and the Kyrgyz Republic (from 4.9 to $4.4=-0.5$ ).

The figures above show a diversity of outcomes in the transformative processes of each country. Some nations were clearly more successful than others in different areas. The main advantage of an index that shows both political and economic democracy, rather than only political democracy, is that it reveals that both areas have to be taken into consideration if we want to understand the full impact of the transformations on the populations and how they react to it. Although certain countries have made great gains (especially in terms of political democracy), all of them worsened their economic democracy. This may be at the heart of a malaise captured in opinion polls in these countries which demonstrate a degree of dissatisfaction within the present regimes (and sometimes even a certain nostalgia for former times among some groups of the population) which is not congruent with the improvements since the last decade (Levada 2000; Polit.ru 2002). This 
new index brings to light and to the public debate the question of economic democracy, without which the transformations of the past years cannot be fully understood.

Since the purpose of this article is to introduce the new triple index in general, we will not analyze in details the implications of the above figures for each country. We will just point out that the table presented could be analyzed in myriad ways: the individual characteristics of the most successful and least successful countries; the development paths apparently more conducive to higher scores in the three areas; how much of the present absolute situation in the three areas is due to legacies from the socialist past and how much is due to the transition itself, etc. Does the index show that there are paths more conducive to both political and economic democracy? Or are the paths to political and economic democracy separate? All these fields of research are extremely rich and will certainly bring new insights. Hopefully the new triple index can spur this kind of research from both liberals and Marxists in fruitful dialogue.

\section{Difficulties and Possible Variations in the Use of the New Index}

Even if one accepts the idea of measuring economic democracy alongside political democracy (which is the main point of this article), there may be interesting debates on how to best use the new index.

In the specific case of the comparative table on the transition countries, one could debate whether the most appropriate approach is to compare the present situation with that of the last years of their respective perestroikas. Some might argue that it would be better to compare the present with the pre-1985 situation (or with the average of the scores of all years of perestroika) since these times were more typical of the socialist experience. All three alternatives have reasonable arguments behind them and would yield different outcomes. For most countries, the gains in political democracy would be greater, and so would the steepness of the fall in economic democracy as our comparisons go further back in time because the socialist regimes then were both more authoritarian and egalitarian. Also, depending on the time each country began to liberalize, the apparent gains in political democracy may seem greater or lesser as a consequence of the base year utilized. In sum, it would bring a healthy and fruitful debate to explore all scenarios possible with the triple index and analyze what results the different comparisons yield.

The main questions I want to highlight here, however, are the ones concerning the joint index per se, independently of the group of countries under analysis. I have already pointed out why I consider the Gini coefficient of income differentials an appropriate rough, initial and provisional proxy for economic democracy (until we construct a better indicator). Although it is not directly related to the form of ownership of the means of 
production (as some Marxists would probably prefer), it captures the allocative result of the use of the means of production, which is actually the gist of the matter as far as the general population is concerned.

The other main objection to using the Gini coefficient would be the problem of comparability. As with almost all cross-national economic indicators, the Gini coefficient raises issues of comparability. Conceptual application and survey methods may vary in different countries, or according to source, contaminating the comparison. There are two solutions to this problem. The most immediate is to carefully examine the survey methodologies and utilize in the comparison the surveys that use similar approaches. Secondly, the very development of the field and utilization of such indicators lead to the standardization of procedures and therefore ever-increasing comparability. For example, for many OECD countries the standardization of statistics, as embodied in the work of the Luxembourg Income Study group, is already a reality. ${ }^{10}$ Hopefully, widening the use of the Gini coefficient in other areas will help spur the ongoing efforts towards ever-greater standardization in cross-national statistics. As we mentioned, the Gini coefficient is a provisional proxy for the initial quantitative incorporation of the economic aspect into the debate on democracy. Its use can be either perfected or substituted as we progress along this previously uncharted road.

In the present demonstration, we directly drew upon the Freedom House scores to designate the level of political democracy of each country. Improvement can also be made to this category. The Freedom House rankings have been criticized in different aspects (especially for a certain degree of ideological bias) and attention to some of these criticisms may improve their methodology. One aspect which I deem technically important would be to promote a change in the scale of their scores (at present from 7 to 1, being 1 the most free and 7 the least free). This creates a crowding in the upper end of the scale with the result that Lithuania, Hungary, Poland, etc. are considered to have achieved the same level of political democracy ( $=1$, or the maximum) as, for instance, Denmark or Sweden. It would be better to have a more open-ended scale, like the Gini coefficient, for example, where the supreme score (denoting perfect equality) is not achievable in practice by any country, so that it better differentiates between the front runners. ${ }^{11}$

One objection my joint index may receive is that using an arithmetic mean between the political democracy and economic democracy indicators is a too simplistic way to measure two qualitatively different magnitudes. My answer to this is threefold. Firstly, the arithmetic mean (instead of some more sophisticated weighted average) expresses the belief that both political and economic democracies are equally important. Secondly, simplicity and concision (in a word, minimalism) have revealed themselves important to break through complex epistemological barriers in the past. Schumpeter's minimalist definition 
of democracy (deemed too simplistic at first by some authors) is one of such cases. Finally, I would like to reiterate that my triple index is an initial attempt to develop a joint indicator of political and economic democracy by means of a minimalist approach (until we are able to later develop a more sophisticated indicator).

I believe my proposed triple indicator stands more reasonably half-way as a "giveand-take" compromise between the Marxist and liberal positions than the other indexes available in our present literature. The Freedom House scores, the Polity Project's democracy and autocracy scales, the Vanhanen polyarchy dataset, and the Coppedge-Reinicke polyarchy scale concentrate on political democracy. Marxists object to this exclusivity and also to the existing indexes of economic freedom, like the Heritage Foundation's Index of Economic Freedom, the EBRD's Transition Indicators, and the Cumulative Liberalization Index by the World Bank's de Melo et al. (1996), which, according to them, measure basically the freedom to pursue business. On the other hand, efforts by Marxist or social-democracy oriented sociologists to operationalize concepts closer to economic democracy such as, for example, the erstwhile burgeoning literature on workplace democracy and workers' control of past decades remained overall normative and descriptive. As such, they failed to produce a quantifiable index which could satisfy the operational requirements of liberal institutionalist political scientists. ${ }^{12}$

All these remarks are for the future. This article will have achieved its objective if it can convince some liberals and some Marxists of the necessity to evaluate and measure both political and economic democracy. It proposes one possible way to do that.

If this challenge is taken on, even if Marxists and liberals work separately, very interesting comparative work can be done in the near future. For instance, to investigate the levels of political and economic democracy of the countries before and after the third wave of democratization; compare the transitions in Eastern Europe and in Latin America; analyze the current transformations in Asian countries, etc.

However, the greatest results would be obtained if Marxists and liberals abandon the zero-sum game attitude between them and engage in a constructive dialogue whereby the purpose is not to "defeat" the opponent, but through discussion reach superior insights, combining the best of each position. My hope is that the use of objective, measurable yardsticks as a means to judge political and economic democracy may be the beginning of an effort to bring the more moderate contenders from both sides to establish a meaningful, unprejudiced discussion of democracy. Historical experience has shown that neither the state nor the market alone can adequately manage the development of modern societies. The Post-World War II decades and the experience of the welfare state have shown that it is possible to simultaneously increase economic efficiency and social justice. This Weltanschauung suffered setbacks in the decades of the eighties and the nineties when 
the radical separation between market and state was again postulated. Thus, attempts to make a dialectical synthesis of the two apparent opposites, Marxism and liberalism, become important not only in theoretical, but also in practical terms. It is necessary to recover the notion that state and market, social justice and efficiency, economic and political democracy are not opposites per se and can come together in a more harmonious manner.

Finally, is it too utopian to imagine that maybe a Hegelian synthesis between the camps of Marxism and liberalism will in the future be reached and in the historical practice eventually a society will emerge possessing both political and economic democracy to the highest degrees?

Revised by Sandra Gomes Submitted in October 2011

Accepted in October 2012

\section{References}

Blumberg, Paul. 1968. Industrial Democracy: The Sociology of Participation. London: Constable.

Bobbio, Norberto. 1983. Qual Socialismo? Rio de Janeiro: Paz e Terra.

Brinton, Crane, Christopher, John B., and Wolff, Robert Lee. 1965. Civilization in the West. Englewoods Cliffs: Prentice Hall.

Cloutier, Bernard. 2007. Gini Coefficients. http://berclo.net/page01/01en-gini-coef.html (accessed September 10, 2007).

Coppedge, Michael, and Reinicke, Wolfgang. 1990 "Measuring Polyarchy". Studies in Comparative International Development, vol. 25, n. 1, pp. 51-72.

Diamond, Larry, Linz, Juan J., and Lipset, Seymour Martin. 1989. Politics in Developing Countries: Latin America. Boulder: L. Rienner Publishers.

Greskovits, Bela. 1998. The Political Economy of Protest and Patience: East European and Latin American Transformations Compared. Budapest: Central European University Press.

Held, David. 1987. Models of Democracy. Cambridge, UK: Polity Press.

Hunnius, Gerry, Garson, G. David, and Case, John. 1973. Workers' Control: a Reader on Labor and Social Change. New York: Vintage Books.

Huntington, Samuel. 1991. The Third Wave: Democratization in the Late Twentieth Century. Norman: University of Oklahoma Press.

Innocenti Research Center. 2006. TransMONEE 2006 Database: http://www.unicef-icdc.org/ resources/transmonee.html (accessed January 10, 2007).

Lenin, Vladimir Ilich. 1943. State and Revolution. New York: International Publishers. 
Levada, Yurii. 2000. Ot Mnenii k Ponimaniyu: Sotsiologicheskie Ocherki, 1993-2000. Moscow: Moskovskaya Shkola Politicheskikh Issledovanii.

Madison, James. 1999. Writings. New York: Literary Classics of the United States.

Mainwaring, Scott, Brinks, Daniel, and Perez-Linen, Anibal. 2001. "Classificando Regimes Políticos na América Latina". Dados vol. 44, n. 4, pp. 645-687.

Melo, Martha de, Denizer, Cevdet, and Gelb, Alan. 1996. "Patterns of Transition from Plan to Market". The World Bank Economic Review, vol. 10, n. 3, pp. 397-424.

Nelson, Joan, ed. 1994. Intricate Links: Democratization and Market Reforms in Latin America and Eastern Europe. Oxford: Transaction Publishers.

O’Donnel, Guillermo. 1999. "Teoria Democrática e Política Comparada". Dados, vol. 42, n. 4, pp. 577-654.

O’Donnell, Guillermo, and Schmitter, Phillip C. 1988. Transições do Regime Autoritário: Primeiras Conclusões. São Paulo: Vértice.

Polit.ru. 27 Dec. 2002. Gody Nadezhd, Razocharovaniya i Terpeniya: Pyatnadtsaty Let v Oprosakh VTSIOM. http://www.polit.ru (accessed December 10, 2002).

Przeworski, Adam, Alvarez, Michael, Cheibub, José Antonio, and Limongi, Fernando. 1997. "O Que Mantém as Democracias?". Lua Nova, n. 40/41, pp. 113-135.

Przeworski, Adam. 1991. Democracy and the Market: Political and Economic Reforms in Eastern Europe and Latin América. Cambridge, UK: Cambridge University Press.

Rousseau, Jean-Jacques. 1947. The Social Contract. New York : Hafner Pub. Co.

Schmitter, Phillip C., and Karl, Terry Lynn. 1996. "What Democracy Is... and What Is Not". In: The Global Resurgence of Democracy, edited by Larry Diamond and Marc F. Plattner. Baltimore: The Johns Hopkins University Press.

Schumpeter, Joseph. A. 1984. Capitalismo, Socialismo e Democracia. Rio de Janeiro: Zahar.

Stephens, Evelyne Huber. 1980. The Politics of Workers' Participation: the Peruvian Approach in Comparative Perspective. New York: Academic Press.

United Nations University. 2005. UNU-WIDER World Income Inequality Database, Version 2.0a. http://www.wider.unu.edu/wiid/wiid.htm (accessed January 10, 2007).

World Bank. 2002. The First Ten Years: Analysis and Lessons for Eastern Europe and the Former Soviet Union. Washington, DC: World Bank.

\section{Notes}

1 As noticed by O'Donnel $(1999,484)$, Schumpeter's definition of democracy is not so minimalist as it appears at first sight. The adjective comparative has crucial significance. If the democratic method is basically the competitive struggle for the people's vote, in order for this struggle to 
proceed properly a series of pre-conditions must be present. Among them, Schumpeter (1984, 338,341 ) himself lists the freedom of the press and of discussion, without which there can be no "free competition for the free vote".

2 The exception was the ten generals elected every year to command the army and the navy. They could be reelected indefinitely. Pericles, for example, was reelected for 30 years (Brinton et al., 1965, 26-27).

3 Although he did not put things in these terms, it is important to notice that Rousseau is not particularly in favor of direct democracy in the executive branch of power. Sovereignty, i.e., the power to rule (legislate) over oneself, refers, in his view, to the legislative branch. Laws must be ratified directly by the people. Now, the executive power, i.e., the more mechanical or formal aspect of merely carrying out these laws (wishes) of the people, can be entrusted to some persons who will faithfully carry it out. There is a certain analogy here with the postindependence U.S.A., in which some Founding Fathers had the idea that the legislative branch of government would be the powerful one, with the executive branch merely "executing" the orders (laws) of Congress.

4 People understood as citizens.

5 The question of whether or not direct democracy is possible in present-day large nation-states is controversial. It is frequently pointed out that once home computers (or, at least, access to computers) become universalized (like radio and TV in the past) the technical difficulties to carry out nationwide simultaneous computerized voting are actually not big. If Brazil (a "third world" country) can conduct completely computerized voting for executive and legislative posts (with near real-time result announcement) every two years, why could it not conduct every four or six months universal voting or ratification of laws by the whole population? Also important in this regard is to notice that in March 2007 Estonia became the world's first country where internet voting was allowed in a national election.

As the argument of technical difficulties for direct democracy seems to dwindle with the possibilities of electronic voting, we are faced with the evidence that the main obstacles for direct democracy are not of a technical nature, but of a political nature, such as expounded by James Madison in Federalist Paper No. 10 (echoing some arguments against democracy already put forth by Aristotle and Plato).

6 Cf. Norberto Bobbio's (1983, 33-34) famous assessment: "If the historical experience has shown us that so far no socialist system created by means of non-democratic methods (i.e., by revolution or conquest) could become democratic, it has also shown us that capitalist systems cannot become socialist democratically [...] In capitalist states, the democratic method, even in its best formats, closes the road to socialism; in socialist states, the concentration of power from a unified controlling center of the economy makes extremely difficult the introduction of the democratic method".

7 In income terms, economic inequality is measured by means of the Gini coefficient. The Gini coefficient varies from zero (= absolute equality) to one (= one persons owns all the wealth of a country). Historically the Gini coefficient varied from around 0.2 in more egalitarian socialist countries of Eastern Europe before perestroika (e.g., Czechoslovakia, Hungary) to around 0.6 in extremely inegalitarian countries, like Brazil and Guatemala. The average of the OECD countries is around 0.3 (World Bank 2002; Cloutier 2007).

8 The provisional utilization of the Gini coefficient as a rough, initial proxy for the level of economic democracy may also bypass the possible barrier of a criticism often leveled at the 
Marxist defense of the collective property of the means of production as more democratic than private property. Many non-Marxist economists say that the end goal of production is consumption and that, since state socialist property is administered inefficiently, most of the population will have a higher standard of living if factories and other units of production are privatized and more efficiently run. Then, via taxation, the larger income may be redistributed to the population (the Keynesian welfare state model). In other words, with a privatized, but better run, economy most of the population will have a higher standard of living (via redistribution of income by means of taxation) than in a society where the means of production are socialized, but ill administered. This was the ratio decidendi behind the privatization processes in Eastern Europe. The utilization of the Gini coefficient has the side (beneficial) effect of covering this reasoning, since it measures economic democracy on the output side, i.e., according to income or wealth produced, not according to the mere possession of means of production.

9 See the Freedom House website at http://www.freedomhouse.org.

10 See Luxembourg Income Study website at http://www.lisproject.org.

11 Theoretically, the supreme score of such a Gini coefficient-like scale of political democracy would be the level achieved by a society with direct, free democracy and fully universal suffrage. The closer a society (by different mechanisms, including indirect representation) comes to this (in historical practice so far unreachable) ideal, the more democratic it would be. See the discussion on the historical roots of direct democracy at the beginning of the article in order to understand the logic of this reasoning.

12 For the indexes mentioned, see the Freedom House website at http://www.freedomhouse.org; Polity IV Project website at http://www.cidcm.umd.edu/polity; Vanhanen's Polyarchy dataset at http://www.svt.ntnu.no/iss/data/Vanhanen; Coppedge \& Reinicke 1990; Index of Economic Freedom website at http://www.heritage.org/index; Transition Report (various years) at http:// www.ebrd.com and Melo et al., 1996. For literature on workplace democracy or workers' control see, for example, Blumberg 1968, Hunnius et al. 1973, Stephens 1980. 